\title{
CHALLENGES AND OPPORTUNITIES TO ACCESS HEALTH CARE IN URBAN SLUMS OF LAGOS-STATE IN NIGERIA
}

\author{
Bolaji Samson Aregbeshola ${ }^{1}$, Olanrewaju Olusola Onigbogi ${ }^{1}$ and Samina Mohsin Khan ${ }^{2}$
}

${ }^{1}$ Department of Community Health \& Primary Care, College of Medicine, University of Lagos, Idi-Araba, Mushin, Lagos, Nigeria.

${ }^{2}$ Department of Public Health Sciences Karolinska Institutet, Stockholm, Sweden

Corresponding Author: Bolaji Samson Aregbeshola. Email: bolajiaregbeshola74@gmail.com

\begin{abstract}
Background

Access to healthcare is a major public health challenge, especially in developing countries. Many Nigerians cannot avail the healthcare services they need with those in the urban slums being the worst hit. The aim of the study is to determine the issues regarding accessibility ofhealthcare services in three urban slums of Lagos State in Nigeria. All the aspects of accessibility including the geographical, financial and socio-cultural factors affecting the healthcare access were assessed.

Methods: A descriptive cross-sectional study was conducted among slum dwellers of three urban slums in Lagos-State.A sample size of 427 individuals was used. The subjects were recruited using multi-stage sampling technique. Data was collected using a structured self-administered and close-ended questionnaire that was adapted from World Health Organization. Variables on geographical accessibility, financial accessibility and social-cultural factors affecting accessibility were analysed. Data analysis was performed using SPSS version 15 software.

Results: A total of $80.3 \%$ of the respondents had an estimated travel distance ranging from 6 to $10 \mathrm{~km}$ to reach a healthcare facility. About $10-20 \%$ of the monthly household income was spent on healthcare by $46.8 \%$ of respondents. A total of $97.9 \%$ of respondents had no health insurance coverage. Self-medication was reported by $77.8 \%$ of the respondents who were unable to pay for healthcare services. Only $43.1 \%$ of respondents utilized government hospitals as the first point of contact.

Conclusion: Our study concludes that there is limited geographical and financial access to healthcare services for slum dwellers in Lagos-State especially due to their financial constraints that affect their accessibility to healthcare services. Access to healthcare services still remains a major issue in slums of Nigeria. Increasing the coverage of the National Health Insurance Scheme and strengthening the primary healthcare infrastructure would help in addressing the issues of accessibility to healthcare in urban slums.
\end{abstract}

Keywords: Access to health care services, health system, urban slums, Lagos State, Nigeria

\section{Introduction}

Accessibility still remains a major public health challenge to deal with in health systems research especially in low income countries (LICs). The meager resources in low income countrieslimitthe access to health services than high income countries (1). So is true for Sub-Saharan Africa where accessibility of health care services still plays a hurdle for optimum health systems performance (2). Many Nigerians cannot avail the health care services they need with those in the urban slum being the worst hit. Nigeria's health spending as a percentage of Gross Domestic Product (GDP) is 3.7 per cent while the out of pocket (OOP) health expenditure as a percentage of total health expenditure is 73 per cent (3).Alarmingly, out of pocket health expenditure as a percentage of private health expenditure is 95 per cent (3). High out of pocket payment is a barrier to health care accessibility for poor communities andremains an inequitable means of financing health care system. This inequitable distribution of resources leads to inequitable and unequal distribution of both public and private health care facilities that adds to the dilemma. According to any country'sstandard, there should, at least, be a primary health center (PHC) within a five kilometer radius (4) from where most patients are examined and appropriate referrals are made (5). Improved access to health care has and continues to be a "fundamental objective of healthpolicy making" for optimum health system performance (6).

Despite that substantial research has been conducted focusing on access to health care and sustained attention to accessibility issues in health policies, in 
the context of health services research, community and policy makers continue to seek answers to this fundamental question (7). The large gap in access to health care services between different groups in both developed and developing countries is well established (8).Although many Nigerian have to walk more than five kilometres to access health care services which are often times inefficient, ineffective and not affordable but the situation especially adds to the vulnerability of people living in urban slums of Nigeria that pushes them in a vicious cycle of poverty and makes them to experience adverse health outcomes.

Today, nearly 1 billion people or $32 \%$ of the world's urban population is estimated to be living in slums. An estimated 72 percent of the urban population in Africa now lives in slums. In sub-Saharan Africa, the proportion of urban residents in slums is highest at 71.9 per cent (9). While their physical forms vary to place and over time, slums are uniformly characterized by the inadequate provision of basic infrastructure and public services necessary to sustain health such as water, sanitation and drainage (10). These poor or low-income urban human settlements, comprising between $25 \%$ and $75 \%$ of urban population occupies irregular settlements including squatter settlements, unauthorized land developments and rooms and flats in dilapidated buildings in city centre area (11). Although there are no accurate figures but Nigeria has a fair share of these low-income settlements (12). Many Nigerian cities are typified by substandard and inadequate housing slums with lack of infrastructure, transportation problems, low productivity, crime and juvenile delinquency (13).So is the city of Lagos that represents the epitome of urban decay (14). The metropolis is replete with environmental problems ranging from slums and squatter settlements to crime and delinquency (14).In 1984, 42 settlements have been identified as blighted and the number has risen to about 100 in 2004 whereby a 2002 survey revealed that over $70 \%$ of the built up area of Lagos metropolis is blighted $(14,15) . I n$ 2006, the Lagos State government embarked on a US\$200 million World Bank funded urban upgrading project, the Lagos Metropolitan Development and Governance project designed to increase sustainable access to basic urban services through investments in critical infrastructure in nine target communities namely Agege, Ajegunle, Amukoko, Bariga, ljeshatedo/ltire, Ilaje, Iwaya and Makoko (16). Inadequacy of decent housing has resulted in the Lagos State Section of the Lagos Mega-city region (LMCR) recording 42 slums areas in 1985 and over 100 in 2006 (17).

Over two-third of the population of Lagos consequently lives in the informal settlements and slums that are scattered around the city $(18,19)$. The areas still face challenges of accessibility that contribute to significant delays in accessing health care due to inadequate infrastructure including lack or poor condition of roads as well as poor transport systems (4).

There is limited evidence on issues related to access and equity in health care delivery system in urban settings of Nigeria. This study aims to determine the issues regarding accessibility ofhealth care services in three urban slums of Lagos State in Nigeria. Specifically, the study examined all the aspects of accessibility including the geographical, financial and socio-cultural factors affecting the health care access in three urban slums of Lagos State. The study contributes to knowledge on access to health care services in urban slums of Lagos State in Nigeria.

\section{Methodology:}

The study was conducted in three urban slums of Lagos State namely Mushin-Idi-Araba, Ajegunle and ljoraBadia. These slums were selected among the over 100 slum communities in Lagos State using the simple random sampling technique between June and December 2012. The decision to carry out the study in these three urban slums was to ensure effective coverage and better focus thereby assuring the accuracy and quality of data. Lagos State is the commercial nerve center of Nigeria with an estimated population of 21 million people (20). However, Mushin Idi-Araba is located in Mushin Local GovernmentArea of Lagos State. It is a slum community that is predominantly occupied by the Hausa ethnic group. Ajegunleis also located in Ajeromi-Ifelodun Local Government Area of Lagos State. It is a major slum with multi-ethnic population. The dominant ethnic groups in Ajegunle are the ljaw, Urhobo and Isekiri. ljoraBadiais an urban slum settlement located in Apapa Local Government area of Lagos State. The respondents were recruited using multi-stage sampling technique as the same technique was utilized in similar type of studies carried out in Nigeria $(21,22)$. The first stage involved the simple random sampling of three urban slums among the over 100 slum communities in Lagos. The second stage involved generating a list of houses in each slum. The third stage was the selection of one in three houses through a systematic sampling technique. The fourth stage involved the selection of individuals (men and women aged 20 years and older living in the urban slum) in each house by simple random sampling (balloting) where more than one individual met the inclusion criteria. The exclusion criteria aremen and women under the age of 20 yearsand not living in the urban slum. Where no individual met the criteria in a house, the next house was used. This was done until 10 individuals were selected per street in each of the three urban slums and till the required 427 respondents were recruited into the study. The study participants were individuals (men and women of 20 years and above) living in the three urban slums of 
Lagos State. The sample size of 427 individuals was calculated using Cochrane equation (23). Based on the assumption that $50 \%$ of individuals living in the three urban slums would have no access to health care and a non-response rate of $10 \%$, the sample size for the study was calculated as 384.Adjusted sample size therefore, the sample size for the study was 427 . Sample size was equally divided within the three slum communities.Data was collected with the aid of a structured self-administered and close-ended questionnaire that was adapted fromthe World Health Organization (WHO) (24). The questionnaire was used to gather information regarding population characteristics of respondents, geographical accessibility, financial accessibility and socio-cultural factors affecting healthcare accessibility. Section A of the questionnaire seeks to generate information about the respondents. Section $B$ focuses on geographical accessibility. Section C seeks information on financial accessibility. Section D of the questionnaire concentrates on the socio-cultural factors affecting healthcare accessibility. There were twenty nine questions altogether. The questionnaire was pre-tested by the researchers in the three urban slums to test its reliability and validity. The questionnaire was thereafter revised. Prior to administering the questionnaire, the researchers informed the respondents about the objectives of the study and obtained their informed consent. Each respondent completed the questionnaire between 1530 minutes. The response rate was 100 per cent.Data was processed using EPI info windows version and analysed with SPSS version 15 software. Descriptive statistical technique was used for the analysis of data in the form of frequency tables and simple percentages for the population characteristics as well as the different measures of access to health care services.Ethical clearance was obtained from Lagos University Teaching Hospital Health Research and Ethics Committee and permission was sought from local authorities prior to data collection. Respondents were briefed on the purpose and objective of the study and their informed consent was thereafter obtained while the confidentiality of the data was assured and guaranteed.

Results: The study population consisted of 156 $(36.5 \%)$ and $271(63.5 \%)$ males and females, respectively. The mean age of the respondents was found to be $42.44 \pm 13.76$. The majority of the respondents were aged between $30-39$ years (25.3\%). Among the study population, $42.8 \%$ attained primary education while $28.6 \%$ had secondary education. Majority (85.5\%) of respondents had trading and artisan as their occupation while $6.1 \%$ are unemployed. A total of $36.3 \%$ of respondents are lgbo while $32.8 \%$ are from the Yoruba ethnic group. The details of the population characteristics of respondents are shown in Table 1.
Table 1 - Population Characteristics of respondents

\begin{tabular}{|c|c|c|}
\hline Variables & Frequency ( $n=427)$ & Percent (\%) \\
\hline \multicolumn{3}{|c|}{ Age at as last birthday } \\
\hline $20-29$ & 96 & 22.5 \\
\hline $30-39$ & 108 & 25.3 \\
\hline $40-49$ & 83 & 19.4 \\
\hline $50-59$ & 78 & 18.3 \\
\hline$>60$ & 62 & 14.5 \\
\hline \multicolumn{3}{|l|}{ Sex } \\
\hline Male & 156 & 36.5 \\
\hline Female & 271 & 63.5 \\
\hline \multicolumn{3}{|l|}{ Level of Education } \\
\hline None & 20 & 4.7 \\
\hline Primary & 183 & 42.8 \\
\hline Some secondary & 77 & 18.0 \\
\hline Secondary & 122 & 28.6 \\
\hline Tertiary & 25 & 5.9 \\
\hline \multicolumn{3}{|l|}{ Occupation } \\
\hline Civil service & 21 & 4.9 \\
\hline Trading and Artisan & 365 & 85.5 \\
\hline Unemployed & 26 & 6.1 \\
\hline Others & 15 & 3.5 \\
\hline \multicolumn{3}{|l|}{ Ethnic group } \\
\hline Igbo & 155 & 36.3 \\
\hline Yoruba & 140 & 32.8 \\
\hline Hausa & 83 & 19.4 \\
\hline Others & 48 & 11.5 \\
\hline
\end{tabular}

Geographical accessibility: Table 2 shows that a total of $80.3 \%$ of the respondents have an estimated travel distance from $>5 \mathrm{~km}$ to $10 \mathrm{~km}$ to reach a health care facility. Only $71.2 \%$ of respondents spend between $>15$ - 30 minutes traveling to reach a health care facility. A total of $68.2 \%$ of the study population describe the condition of roads to health facility as bad. Two third $(67.7 \%)$ of the study sample had a motorcycle (Okada) as the mode of transport to a health facility.

Table 2-Geographical accessibility

\begin{tabular}{|l|l|l|}
\hline Variables & Frequency(n=427) & Percent (100\%) \\
\hline Estimated travel distance & 72 & 16.9 \\
\hline- & 343 & 80.3 \\
\hline$>5-10 \mathrm{~km}$ & 12 & 2.8 \\
\hline$>10-20 \mathrm{~km}$ & 117 & 27.4 \\
\hline Estimated travel time & 304 & 71.2 \\
\hline$<15$ minutes & 6 & 1.4 \\
\hline$>15-30$ minutes & \multicolumn{2}{|l|}{} \\
\hline$>31-45$ minutes & 96 & 22.5 \\
\hline Mode of transport to health facility (public and private) \\
\hline Public bus & 23 & 5.4 \\
\hline Walking & 289 & 67.7 \\
\hline Motor Cycle (Okada) & 19 & 4.5 \\
\hline Private car & - & - \\
\hline Water &
\end{tabular}




\begin{tabular}{|l|l|l|}
\hline \multicolumn{3}{|c|}{ Condition of roads to health facility (public and private) } \\
\hline Very bad & 35 & 8.2 \\
\hline Bad & 291 & 68.2 \\
\hline Normal & 79 & 18.5 \\
\hline Good & 18 & 4.2 \\
\hline Excellent & 4 & 0.9 \\
\hline Total & 427 & 100 \\
\hline
\end{tabular}

Financial accessibility: More than half of the study population $(58.1 \%)$ had a household monthly income of less US $\$ 64.1$ while $38.6 \%$ had a monthly income between US $\$ 64.1$ - US $\$ 128.2$. A total of $23 \%$ of the study population spent less than $10 \%$ of household income per month on health care while $46.8 \%$ of respondents had spent between $10-20 \%$ of the household income. A higher proportion $(70 \%)$ of respondents had between US\$3.2 - US\$6.4 as their monthly cost of transport to health care facility. Our study also found that $41.5 \%$ of the study population had between US\$3.2 - US\$6.4 as cost of consultation while $44 \%$ spent between US\$6.4 - US\$6.4 on consultation. A total of $61.1 \%$ of respondents had between US\$12.8 - US $\$ 25.6$ as the cost of treatment per month while only $23.9 \%$ spent less than US $\$ 12.8$ as treatment cost on a monthly basis. It was found that $46.4 \%$ of the study population spent less than US $\$ 12.8$ out of pocket for treatment per month while $43.1 \%$ spent between US\$12.8 - US\$25.6 as out of pocket expenditure for treatment per month. A total of $97.9 \%$ of respondents are not under any health insurance scheme. As high as $77.8 \%$ of the study population reported self-medication due to their inability to pay for health care services. Details are given in Table 3.

\section{Table 3 - Financial accessibility}

\begin{tabular}{|c|c|c|}
\hline & $\begin{array}{c}\text { Frequency } \\
(n=427)\end{array}$ & $\begin{array}{c}\text { Percentage } \\
(100 \%)\end{array}$ \\
\hline \multicolumn{3}{|l|}{ Household monthly income } \\
\hline$<\mathrm{N} 10,000(\mathrm{US} \$ 64.1)$ & 248 & 58.1 \\
\hline $\begin{array}{l}\text { N10,000 - N19,999 (US\$64.1 - } \\
\text { US\$128.2) }\end{array}$ & 165 & 38.6 \\
\hline $\begin{array}{l}\text { N20,000 - N20,999 (US\$128.2 - } \\
\text { US\$134.6) }\end{array}$ & 6 & 1.4 \\
\hline $\begin{array}{l}\text { N30,000 - N30,999 (US\$192.3 - } \\
\text { US\$198.7) }\end{array}$ & 1 & 0.2 \\
\hline$>\mathrm{N} 40,000(\mathrm{US} \$ 256.4)$ & 7 & 1.6 \\
\hline \multicolumn{3}{|c|}{ Percentage of household income spent on health care } \\
\hline$<10 \%$ & 98 & 23.0 \\
\hline $10-20 \%$ & 200 & 46.8 \\
\hline $21-30 \%$ & 125 & 29.3 \\
\hline $31-40 \%$ & 2 & 0.5 \\
\hline$>40 \%$ & 2 & 0.5 \\
\hline
\end{tabular}

\begin{tabular}{|c|c|c|}
\hline \multicolumn{3}{|c|}{ Monthly cost of transport to health facility (public and private) } \\
\hline$<\mathrm{N} 500(\mathrm{US} \$ 3.2)$ & 60 & 14.1 \\
\hline $\begin{array}{l}\text { N500 - N999 (US\$3.2 - } \\
01 \text { US } \$ 6.4)\end{array}$ & 299 & 70.0 \\
\hline $\begin{array}{l}\mathrm{N} 1,000-\mathrm{N} 1,999 \text { (US\$6.4 - } \\
\text { US\$12.8) }\end{array}$ & 61 & 14.3 \\
\hline $\begin{array}{l}\text { N2,000 - N2,999 (US\$12.8 - } \\
\text { US\$19.2) }\end{array}$ & 5 & 1.2 \\
\hline$>\mathrm{N} 3,000$ (US\$12.8) & 2 & 0.5 \\
\hline \multicolumn{3}{|l|}{ Cost of consultation per month } \\
\hline$<\mathrm{N} 500$ (US\$3.2) & 42 & 9.8 \\
\hline $\begin{array}{l}\text { N500 - N999 (US\$3.2 - } \\
\text { US\$6.4) }\end{array}$ & 177 & 41.5 \\
\hline $\begin{array}{l}\mathrm{N} 1,000-\mathrm{N} 1,999 \text { (US\$6.4 - } \\
\text { US } \$ 6.4)\end{array}$ & 188 & 44.0 \\
\hline $\begin{array}{l}\text { N2,000 - N2,999 (US\$12.8 - } \\
\text { US\$19.2) }\end{array}$ & 10 & 2.3 \\
\hline$>\mathrm{N} 3,000$ (US\$19.2) & 10 & 2.3 \\
\hline $\begin{array}{l}\text { N2,000 - N2,999 (US\$12.8 } \\
\text { - US\$19.2) }\end{array}$ & 10 & 2.3 \\
\hline$>$ N3,000 (US\$19.2) & 10 & 2.3 \\
\hline \multicolumn{3}{|l|}{ Cost of treatment per month } \\
\hline Free & 12 & 2.8 \\
\hline$<\mathrm{N} 2,000$ (US\$12.8) & 102 & 23.9 \\
\hline $\begin{array}{l}\text { N2,001 - N4,000 (US\$12.8 } \\
\text { - US\$25.6) }\end{array}$ & 261 & 61.1 \\
\hline $\begin{array}{l}\text { N4,001 - N6,000 (US\$25.6 } \\
\text { - US\$38.5) }\end{array}$ & 34 & 8.0 \\
\hline$>\mathrm{N6}, 000$ (US\$38.5) & 18 & 4.2 \\
\hline
\end{tabular}

\section{Out-of-pocket expenditure for treatment per month}

\begin{tabular}{|c|c|c|}
\hline$<\mathrm{N} 2,000(\mathrm{US} \$ 12.8)$ & 198 & 46.4 \\
\hline $\begin{array}{l}\mathrm{N} 2,001-\mathrm{N} 4,000 \text { (US\$12.8 } \\
\text { - US\$25.6) }\end{array}$ & 184 & 43.1 \\
\hline $\begin{array}{l}\text { N4,001- N6,000 (US\$25.6 } \\
\text { - US\$38.5) }\end{array}$ & 29 & 6.8 \\
\hline $\begin{array}{l}\text { N6,001 - N8,000 (US\$38.5 } \\
\text { - US\$51.3) }\end{array}$ & 8 & 1.9 \\
\hline$>\mathrm{N} 8,000$ (US\$51.3) & 8 & 1.9 \\
\hline \multicolumn{3}{|c|}{ Under any health insurance scheme } \\
\hline Yes & & 2.1 \\
\hline No & & 97.9 \\
\hline
\end{tabular}

Result of inability to pay for health care services

\begin{tabular}{|l|l|l|}
\hline Ignored the illness & 34 & 8.0 \\
\hline $\begin{array}{l}\text { Delayed seeking } \\
\text { healthcare }\end{array}$ & 47 & 11.0 \\
\hline Self-medication & 332 & 77.8 \\
\hline
\end{tabular}

Socio-cultural factors affecting health care accessibility: English language was used as a medium of communication with health care provider by $69.8 \%$ respondents. A total of $37.9 \%$ and $36.7 \%$ of 
respondents reported wife/mother and husband/father, respectively as persons who determine when to seek health care. It was found that $57.4 \%$ of study population will not share health facility (public or private) with the Yoruba tribe while $25.3 \%$ of the respondents will not share health facility with the Igbo tribe. A total of $43.1 \%$ of the study population reported government hospital as their first point of contact when seeking health care while $32.6 \%$ reported chemist/pharmacy as their first point of contact. Only $24.1 \%$ of respondents reported private hospital as their first point of contact when seeking health care. There were misperceptions regarding health seeking behaviour among study respondents regarding various diseases. More than half of the respondents (59.5\%) believed mental illness does not necessitate medical attention. Details are given in Table 4.

Table 4 - Socio-cultural factors affecting health care accessibility

\begin{tabular}{|c|c|c|}
\hline & Frequency $(n=427)$ & Percent (100\%) \\
\hline \multicolumn{3}{|c|}{ Language used to communicate } \\
\hline English & 298 & 69.8 \\
\hline Yoruba & 61 & 14.3 \\
\hline Hausa & 24 & 5.6 \\
\hline Igbo & - & - \\
\hline Others & 44 & 10.3 \\
\hline \multicolumn{3}{|c|}{ Who primarily determines when to seek health care } \\
\hline Children & 84 & 19.7 \\
\hline Extended family & 15 & 3.5 \\
\hline Wife/Mother & 162 & 37.9 \\
\hline Husband/Father & 114 & 26.7 \\
\hline Others & 52 & 12.2 \\
\hline \multicolumn{3}{|c|}{$\begin{array}{l}\text { Tribes slum dwe Ilers will not share public and private health } \\
\text { facility with }\end{array}$} \\
\hline Yoruba & 245 & 57.4 \\
\hline Igbo & 108 & 25.3 \\
\hline Hausa & 63 & 14.8 \\
\hline Kanuri & 8 & 1.9 \\
\hline Others & 3 & 0.7 \\
\hline \multicolumn{3}{|l|}{ First point of contact } \\
\hline Chemist/Pharmacy & 139 & 32.6 \\
\hline Private hospital & 103 & 24.1 \\
\hline Government hospital & 184 & 43.1 \\
\hline Others & 1 & 0.2 \\
\hline \multicolumn{3}{|c|}{ Diseases that does not necessitate medical attention } \\
\hline Mental illness & 254 & 59.5 \\
\hline HIVIAIDS & 83 & 19.4 \\
\hline Leprosy & 43 & 10.1 \\
\hline Tuberculosis & 28 & 6.6 \\
\hline Others & 19 & 4.5 \\
\hline Total & 427 & 100 \\
\hline
\end{tabular}

Discussion: Our study shows that there is limited access to health care services among slum dwellers in urban slums of Lagos State. The study revealed that $80.3 \%$ of the respondents had an estimated travel distance ranging from $>5 \mathrm{~km}$ to $10 \mathrm{~km}$ to a health care facility. This was similar to the result of studies conducted in Osun State and Kwara State in Nigeria where people traveled a distance ranging from 6 to 7 $\mathrm{km}$ to access and utilize health care services $(25,26)$. A study in Ghana also found that majority of respondents $(76.4 \%)$ travel more than $4 \mathrm{~km}$ to the nearest health care facility (27). Conversely, a study in Istanbul revealed that majority of the people has a travel distance within $3 \mathrm{~km}$ to a health care facility (28). Only $71.2 \%$ of respondents in the study spent between $>15$ - 30 minutes traveling to a health care facility while two third of the study participants $(67.7 \%)$ had a motorcycleas their mode of transport to reach a health facility.A similar study in Kwara State, Nigeria reported that $55 \%$ of respondents spend less than 40 minutes to seek medical services while $48.8 \%$ of respondents indicated that they in order to seek health care services travel by foot to reach to health centres (26). A study in South Africa found that $70.9 \%$ of respondents traveled for 30 minutes or less to the clinic while $47 \%$ of respondents used a taxi as a mode of transportation to the nearest health facility (29). Results from a study in Indonesia also revealed that a large proportion of respondents $(70 \%)$ spend about 10 minutes traveling to a health facility while $50.5 \%$ of respondents used motorbikes to visit the health centre(30). However, another study in South Africaindicated that $65 \%$ of respondents travel more than 1 hour or more to the nearest health facility while $60.8 \%$ of people walked to clinics in order to access health services (31). Findings from other studies in Lagos State (32) and Edo State in Nigeria (33) revealed that $40 \%$ and $75 \%$ of respondents used public buses respectively while only $38 \%$ of respondents in Lagos State (32) spend between 1530 minutes traveling to government health facilities. More than half of the respondents $(58.1 \%)$ had a household income less than US\$64.1 per month. This agrees with a study carried out in Ajegunle, Nigeria where $48.3 \%$ of the residents earned less than US $\$ 64.1$ a month (21). Our study also shows that $46.8 \%$ of respondents had $10-20 \%$ household income spent on health. This is in contrast with a study conducted in Nigeria (22) where $93.7 \%$ of the respondents spent over $5 \%$ of their income on health care, further it was found in a study from Mexico (34) where each year two to four million households spent $30 \%$ or more of their income on health. The findings are also in line with a study in Vietnam (35) where households spent on average $13.2 \%$ of their income on health care services. The majority of the respondents $(70.0 \%)$ spent between US\$3.2 US\$6.4 per month on transportation to a health 
facility. This is in contrast to a household survey by the Lagos State Government which revealed that only $5 \%$ of households spent more than US\$1.9 on transportation to and from government health centre (32).More than half of the respondents $(61.1 \%)$ spent an amount between US\$12.8 - US\$25.6 on treatment per month. A similar study in Lagos State revealed that $48 \%$ of households reportedly spent less than US $\$ 32.1$ on health care (32). In this study, it was revealed that $94.6 \%$ respondents did out-of-pocket expenditure on purchasing health care services. A similar study in Enugu State, Nigeria revealed that approximately $99 \%$ of payments for healthcare by consumers were out-of-pocket (36).In addition, the study also agrees with findings from Uganda (37) and Ebonyi State in Nigeria (38) where $77 \%$ and $69 \%$ of households respectively did out of pocket expenditure on health care. Majority of the respondents (97.9\%) were not covered by any health insurance scheme. This is in contrast with a study in Oyo State in Nigeria where $83 \%$ of respondents were covered by the National Health Insurance Scheme (NHIS) (39).This could be due to high level of awareness about NHIS, high level of education as well as a high proportion of residents in Oyo State who are mostly government workers. However, the findings agree with a study among Hispanics in the United States (40) where 55\% of the study sample respectively lacked health insurance. A higher proportion of respondents $(77.8 \%)$ reported self-medication as a consequenceof their inability to pay for healthcare services. This is also in contrast with a study in Ghana where a higher proportion of the patients who did not seek health care $(48.1 \%)$ either delay or postpone treatment (41).

The majority of respondents (69.8\%) used English language when communicating with healthcare providers. This is in contrast to a study in the United States where over two-thirds $(69 \%)$ of LimitedEnglish-Proficient (LEP) respondents and $41 \%$ of the English-proficient respondents reported that their physicians spoke their native language when communicating with them (42).Lack of health policies that disproportionately benefits urban slum dwellers has resulted in their continued plight. Governments should learn from the experiences of countries that have been able to effectively address the plight of urban slum dwellers. The provision of functional PHCs and the establishment of a government-run community based health insurance scheme is required to address the problem of accessibility to health care services in urban slums of Lagos State. Investing in health of urban slum dwellers will boost economic growth of the State.

Conclusions: Our study concludes that there is limited geographical and financial access to health care services for slum dwellers in Lagos State especially due to their financial constraints that affect their accessibility to health care services. Access to health care services still remains a major issue in slums of Nigeria. Increasing the coverage of the National Health Insurance Scheme (NHIS) and strengthening the health care system especially the primary healthcare infrastructure within the standard travel distance would help in addressing the issues of accessibility of health care in urban slums. Policy makers need to bring about the much needed change in order to improve the health seeking behaviour of slum dwellers in Lagos State.

\section{References:}

1. Grottret $P$, Schieber $G$. Health financing revisited: a practitioner's guide. Washington DC: The World Bank; 2006.

2. Kruk EM, Freedman LP. Assessing health system performance in developing countries: a review of the literature. Health Policy 2008;85(3):263-276.

3. WHO. Atlas of African Health Statistics 2016: Health situation analysis of the African Region. Congo, Brazaville: World Health Organization Regional Office for Africa, 2016.

4. Kemboi TK, Waithaka EH.GIS locationallocation model in improving accessibility to health care facilities: A case study of Mt. Elgon Sub-County. International Journal of Science and Research2015;4(4): 3306-3310.

5. Chudi IP. Health care problems in developing countries. Medical Practice and Reviews 2010;1(1): 9-11.

6. Organization for economic co-operation and Development. The OECD Health project: Towards high-performing health systems. Paris, France: OECD; 2004.

7. Goldsmith LJ. Access to Health care for disadvantaged individuals: a qualitative inquiry. (PhD Thesis). The University of North Carolina at Chapel Hill; 2007

8. Ensor T, Cooper S. Overcoming barriers to health services access and influencing the demand side through purchasing. Health, Nutrition and Population (HND) discussion paper. The International Bank for Reconstruction and Development/The World Bank; 2004.

9. UN-HABITAT. The challenges of slums: global report on human settlement 2003. Available at http://mirror.unhabitat.org/pmss/listltemDetails. aspx?publicationID=1156Accessed 23 May 2013.

10. Sclar ED, Northridge ME. Slums, slum dwellers and health. American Journal of Public Health2003;93(9): 1381.

11. Chome J. Behavioural and spatial impacts of title registration in informal settlements: the case study of Blantyre city, Malawi. (MSc thesis). International Institute for Geo-Information Science \& Earth Observation, Enschede, The 
Netherlands; 2002.

12. Agbola T, Olatubara CO. "Private sector driven housing delivery (in Nigeria): Issues, constraints, challenges and prospects". A lead paper presented at the 2nd Annual National Workshop on private sector Driven Housing Delivery in Nigeria, University of Lagos, 30th -31st July, 2003.

13. Mabogunje A. Reconstructing the Nigerian city: the new policy on urban development and housing. Paper presented at a national conference on the city in Nigeria, Ile-Ife. 2002.

14. Oduwaye L, Lawanson TO. Poverty and environmental degradation in Lagos metropolis. $2011 . \quad A v a$ i l a b l e from http://dspace.africaportal.org/jspui/bitstream/12 3456789/35409/1/Poverty\%20And\%20Environ mental\%20Degradation\%20In\%20Lagos\%20M etropolis\%20(1).pdfAccessed 23 May 2013.

15. Nubi TO, Omirin MM. Urban violence, land rights and the environment. Paper presented at International Conference on Environmental Economic and Conflict Resolution, Nigeria: University of Lagos; 2006.

16. Morka FC. A place to live: a case study of the ljora-Badia community in Lagos, Nigeria. Case study prepared for enhancing urban safety and security. 2007 . Available at h t t p: / / un ha bitat.org / w p content/uploads/2008/07/GRHS.2007.CaseStu dy.Tenure.Nigeria.pdfAccessed 23 May 2013.

17. Ilesanmi AO. Urban sustainability in the context of Lagos mega-city. Journal of Geography and Regional planning2010;3(10): 240 -252.

18. Federal Republic of Nigeria. Report of the presidential committee on redevelopment of Lagos megacity region. Abuja: Federal Republic of Nigeria; 2006.

19. World Bank. Nigeria - Lagos metropolitan development and governance project. 2006. A v a i I a b I e a t http://documents.worldbank.org/curated/en/142 611468096552955/pdf/36433.pdfAccessed 23 May 2013.

20. World Population Review. Lagos Population 2016 . A v a i l a b I e a t http://worldpopulationreview.com/worldcities/lagos-population/ Accessed 23 December 2016.

21. Olajide O. Urban poverty and environmental conditions in informal settlements of Ajegunle, Lagos, Nigeria. A review paper by REAL CORPS. $2010 . \quad A \vee a$ i I a b I e a t http://www.geomultimedia.org/archive/CORP20 10 148.pdfAccessed 23 May 2013.

22. Olujimi JAB. Accessibility of rural dwellers to healthcare facilities in Nigeria: the Owo region experience. Pakistan Journal of Social
Sciences2007;4(1): 44-55.

23. Cochran WG (1977). Sampling Techniques (Third ed.). Wiley. ISBN 0-471-16240-X. A v a i I a b I e a t https://hwbdocuments.env.nm.gov/Los\%20Ala mos\%20National\%20Labs/General/14447.pdfA ccessed 23 December 2016.

24. World Health Organization. Manual for the household survey to measure access and use of medicines. Geneva: World Health Organization; 2011.

25. Ajala OA, Sanni L, Adeyinka SA. Accessibility to healthcare facilities: a panacea for sustained rural development in Osun State, South Western Nigeria. Journal of Human Ecology2005;18(2): $121-128$.

26. Usman BA, Sulyman OA. Transport and access to rural health centers in Ilorin East local government area, Kwara State, Nigeria. 2011. Available athttp://www.unilorin.edu.ng. Accessed 12 June 2013.

27. Nyatepe DE. Accessibility to health care in the GA West Municipal Area. (MPhil thesis) University of Ghana, Legon; 2014.

28. Kara F, Egresi IO. Accessibility to health care institutions: A case study using GIS. International Journal of Scientific Knowledge 2013;3(4): 1627.

29. Nteta TP. Accessibility \& utilization of the primary healthcare services in Tshwane region. (MPH thesis) National School of Public Health, Faculty of Health Science, University of Limpopo; 2009.

30. Shrestha J. Evaluation of access to primary health care: a case study of Yogyakarta, Indonesia. (M.Sc thesis). International institute for Geo-information Science \& Earth Observation; 2010

31. Tanser F, Gijsbersten B, Herbst K. Modelling and understanding primary healthcare accessibility and utilization in rural South Africa: an exploration using a geographical information system. Social Science \& Medicine 2006;63(3): 691-705.

32. Lagos State Government. Household survey 2010 edition. The Secretariat, Alausa, Ikeja: Lagos Bureau of Statistics, Ministry of Economic Planning \& Budget; 2010.

33. Agbogidi J, Azodo CC. Experiences of the elderly utilizing health care services in Edo State. The International Journal of Geriatrics \& Gerontology2009;5(2).

34. Knaul FM, Frenk J. Health insurance in Mexico: achieving universal coverage through structural reform. Health Affairs 2005;24(6): 1467-1476.

35. Segall M, Tipping G, Lucas H, Dung TV, Tam NT, Vinh DX et al. Economic transition should come with a health warning: the case of Vietnam. Journal of Epidemiology and Community 
Health2002;56: 497-505.

36. Onwujekwe O, Uzochukwu B, Onoka CA. Assessing the use and cost of health care services and catastrophic expenditure in Enugu and Anambra State. Policy Brief of the Consortium for Research on Equitable Health System (CREHS). 2011. Available at http://www.resyst.Ishtm.ac.ukAccessed 12 June, 2013.

37. Ruhweza M, Baine SO, Onama V, Basaza V, Pariyo G. Financial risks associated with healthcare consumption in Jinja, Uganda. African Health Sciences2009;9(2):s86-9.

38. Oyibo PG. Out-of-pocket payment for health services: constraints and implications for government employees in Abakaliki, Ebonyi State, South East, Nigeria. African Health Sciences2011;11(3): 481-485.

39. Sanusi RA, Awe AT. An assessment of awareness level of national health insurance scheme (NHIS) among health consumers in Oyo State, Nigeria. The Social Sciences Medwell Journal2009;4(2): 143-148.

40. Dubard CA, Cuzlice Z. Language spoken \& differences in health status, access to care and receipt of preventive services among US Hispanics. American Journal of Public Health November. 2008;98(11): 2021-2028.

41. Gobah FFK, Liang Z. The national health insurance scheme in Ghana: prospects and challenges: a cross-sectional evidence. Global Journal of Health Science2011;3(2): 1-12.

42. Wilson $E$, Chen AH, Grumbacli $K$, Wang F, Fernandez (2005). Effect of limited English proficiency and physician language on healthcare comprehension. Journal of General Internal Medicine2005;20(9): 800-806. 